\title{
The Role of Acculturation in the Civic Engagement of Latino Immigrants
}

\author{
Cristina Michele Tucker \\ Anna Maria Santiago
}

\begin{abstract}
Despite continued growth and dispersion of the Latino immigrant population in the United States, the lingering effects of a sluggish national economy and growing antiimmigrant sentiments have contributed to ongoing marginalization and exclusion, further hindering their participation in American civic life. Despite these challenges, Latino immigrants have remained engaged, yet the factors and processes that facilitate participation in American society remain poorly understood. Data from the Latino National Survey and focus groups with Latino immigrants were used to examine how variations in levels of acculturation, demographic characteristics, socioeconomic status (SES), and characteristics of the immigrant experience influence the civic engagement of Latino immigrants in American society. We found that citizenship, length of residence in the United States, and higher SES enhanced civic engagement, while brown skin color, migration for economic reasons, and Mexican ancestry decreased participation. The level of acculturation significantly moderated the effects of these contextual factors.
\end{abstract}

Key words: Civic engagement, acculturation, Latinos, incorporation, immigration

Over the past four decades, the Latino immigrant population in the United States has increased rapidly and has dispersed to a broader range of geographic locations throughout the country (DeSipio, 2011; Fischer \& Tienda, 2006; Fraga et al., 2010; Passel, 2005, 2009; Pew, 2007; Smith, 2008; U.S. Census Bureau, 2010a). Latinos, both immigrants and those born in the United States, are estimated to total $25 \%$ of the U.S. population by the year 2050, and have already become the statistical majority population in several states (Fraga et al., 2010; Passel, 2005, 2009; Pew, 2007; U.S. Census Bureau, 2009a, 2009b, 2010a; Wampler, Chávez, \& Pedraza, 2009). At the same time, however, Latino immigrants continue to be marginalized within American society and underserved by U.S. social service delivery systems (Deaux, 2011; Delano, 2011; Moore \& Pinderhughes, 1993; Telles \& Ortiz, 2008). Of equal concern, Latino immigrants historically have been excluded from multiple segments of American society, including middle class suburbs, skilled and white-collar employment sectors, predominantly white schools, and numerous social and community groups (Berry, 2002; DeSipio, 2011; Fischer \& Mattson, 2009; Fischer \& Tienda, 2006; Golash-Boza; 2006; Muñoz, 2008; O'Brien, 2008; Piedra \& Engstrom, 2009; Piore, 1979; Sander \& Putnam, 2010; Telles \& Ortiz, 2008). Moreover, Latino immigrants have been the targets of harmful stereotypes, discrimination, unwarranted police intervention, and racial profiling (Correia, 2010; Fraga et al., 2010; Massey, Durand, \& Malone, 2002; Muñoz, 2008; O'Brien, 2008; Portés, \& Rumbaut, 2006).

Cristina Michele Tucker, Ph.D., is a Bilingual Research Analyst at Ducker Worldwide. Anna Maria Santiago, Ph.D., is the Leona Bevis \& Marguerite Haynam Professor of Community Development in the Mandel School of Applied Social Sciences at Case Western Reserve University in Cleveland. 
Furthermore, there has been a palpable anti-immigrant sentiment surrounding the current wave of Latino immigrants in the United States that heavily overshadows the difficulties experienced by earlier waves of twentieth century European immigrants (DeSipio, 2011; Fraga et al., 2010; Hondagneu-Sotelo, 1999). Recent Latino immigrants have been blamed for an array of contemporary social and economic problems in American society (Correia, 2010; Fraga et al., 2010; Hondagneu-Sotelo, 1999; Wilson, 1999). This anger, emanating from the prolonged economic recession, loss of employment, diminishing state and national coffers, and the reduction of many public services, has grown among the American public (Bacon, 2008; Correia, 2010). However, it may be misplaced, as areas with growing immigrant populations have experienced economic booms, resurgence, and in many cases, increased employment and improved public schools (Fraga et al., 2010). Nonetheless, the popular media has fueled this public outcry, heightening the atmosphere of hostility and the targeting of undocumented immigrants (Bacon, 2008; Correia, 2010; Espenshade \& Hempstead, 1996; Espinosa, 2007; Hondagneu-Sotelo, 1999). This contemporary environment of dislike and poor treatment, within which many Latino immigrants reside, makes their incorporation into American society difficult and their reticence to become involved in civic affairs understandable (Correia, 2010; Santa Ana, 1999; Verba, Schlozman, \& Brady, 1995).

In line with renewed nativism, a growing segment of the American public has focused their efforts on vilifying undocumented immigrants, their family members, and those who help them (Anonymous, 2009; Bacon, 2008; Carlsen, 2009; Perea, 1997). This new nativist movement has spawned anti-immigrant legislation that aims to prosecute undocumented immigrants and sanction mass deportation. One such example was California's Proposition 187, which denied public schooling, health care, and social services to undocumented immigrants and required public employees to report them to immigration authorities. Proposition 187 passed in 1994 by a 3 to 2 margin, but was subsequently overturned by the Supreme Court (Espenshade \& Hempstead, 1996; Fraga et al., 2010). More recently, the state of Arizona passed legislation (SB 1070) requiring police officers to detain anyone suspected to be undocumented, and making it illegal to not carry immigration papers. Many, but not all of the contested provisions in this law were halted by a federal judge and overturned by the Supreme Court. In 2011, the states of Alabama, Indiana, and Georgia passed (anti-immigration) legislation modeled after Arizona's SB 1070. Additionally, in 2006, the U.S. Congress considered HR4437, which would have mandated prosecution of all undocumented immigrants, as well as schools, health centers, community organizations, and churches that assisted in their 'illegal' stay in the United States. The passage of such anti-immigration legislation has led, in some cases, to an increase in the collective civic engagement of Latinos, inciting them to march and protest (Anonymous, 2009; Fraga et al., 2010). On the individual level, however, these events have caused them to retreat for fear of punitive actions by authorities (Anonymous, 2009; Bacon, 2008; Carlsen, 2009; DeSipio, 2011). In the midst of these challenges, Latino immigrants have continued to participate in the civic affairs of receiving communities in the United States. Yet, the factors and processes that contribute to this participation by Latino immigrants remain poorly understood. We seek to address this gap in the current study. 
As a representative democracy, the United States selects the polity to represent them and their interests at all levels of government. The polity is elected by democratic vote, presumably based on the issues that are to become policy, and with the expectation that it represents all segments of the American public (Diamond, 1990, 1994; Van Horn, Baumer, \& Gormley, 2001). Democracy is a deliberation, a negotiation of what is best for all stakeholders (de Souza Briggs, 2008; Diamond, 1990, 1994). Underlying this process is the assumption that all stakeholders should be represented in the deliberation. One critical means by which members of society participate in this deliberation is via civic engagement.

Civic engagement can be understood as individual and community-level involvement in social and political activities that attach people to society and influence multiple levels of policy (Putnam, 2000). According to Putnam (1995), civic engagement is the "people's connection to the life of their community" (p. 2), and is considered the active voice of participation in a representative government, in addition to being a route to understanding American democracy (Borden \& Serido, 2009; McBride, Sherraden, \& Pritzker, 2006; Putnam, 2000). Civic engagement is fundamental to the development of public goods, as well as to matching tangible outcomes to the will of the people (Son \& Lin, 2007; Tuennerman-Kaplan, 2001; Verba et al., 1995). Civic engagement integrates multiple components of communities in which individuals and groups become involved in order to adequately connect with decision makers (Diamond, 1994; García, 2003). Some of these components might be community groups, schools, trade and labor unions, sports teams, religious organizations, workplace organizations, philanthropic organizations, civic groups, government agencies, businesses, recreational organizations, and social service organizations (Putnam, 1995; Son \& Lin, 2007; Verba et al., 1995). The outcome of greater civic engagement is increased connection to public officials and thus more representative public policy and public goods (Diamond, 1994; Putnam, 2000; Son \& Lin, 2007).

However, some individuals and groups in American society are excluded from the democratic process. When particular groups are excluded from the decision-making process and have limited representation, decisions may be biased toward the majority and lead to unjust policy for the unrepresented minority (Bacon, 2008; Diamond, 1990; Putnam, 1995; Verba et al., 1995). In the case of Latino immigrants, exclusion from the decision-making process is linked to issues of acculturation, discrimination, citizenship, anti-immigrant sentiment, and public policy (Correia, 2011; Fraga et al., 2010; García, 2003; Hero, García, García, \& Pachon, 2000; Levin, 2013; Michelson, 2003; Perea, 1997; Sander \& Putnam, 2010).

Given that $44 \%$ of the Latinos residing in the United States are foreign born (U.S. Census, 2010a), it is necessary to understand the political and cultural contexts that shape patterns of incorporation into American society and civic life (Deaux, 2011; DeSipio, 2011; Fraga et al., 2010; Stoll \& Wong, 2007). For example, Latinos emigrating from countries with repressive regimes would have limited knowledge of and exposure to representative democracies (DeSipio, 2011; Massey et al., 2002; Uslaner, 2008; Uslaner \& Conley, 2003; Vedder, Berry, Sabatier, \& Sam, 2009). Further, they may not realize that they have a voice in policy making nor have experience with electing representatives 
to advocate for their needs (Correia, 2010; DeSipio, 2011). To facilitate greater representation, it is paramount that Latino immigrants be encouraged, both directly and indirectly, to become engaged in their local, state, and national communities (DeSipio, 2006, 2011; García, 2003; Massey et al., 2002; Muñoz, 2008; Putnam, 2005; Saito, 2009; Son \& Lin, 2007). However, immigrant feelings toward the U. S. government can be mixed, arising from difficulties with immigration, adversarial relationships between the United States and their countries of origin, and experiences of unfair treatment in American society (Bacon, 2008; Correia, 2010; DeSipio, 2011; Fraga et al., 2010; Muñoz, 2008). Thus, incorporation into American society is an important factor in immigrant involvement in civic life and the representation of their interests in American policy (Deaux, 2011; Massey et al., 2002; Papademetriou \& Terrazas, 2009; Sánchez Molina, 2008).

In this study, we seek to identify possible causal pathways associated with patterns of incorporation and civic engagement of Latino immigrants within American society. Specifically, we employ acculturation and civic engagement theories to examine how variations in immigrant demographic characteristics, socioeconomic status, and characteristics of the immigrant experience influence civic engagement. Further, we examine the role of acculturation as a potential moderator of such engagement. To address these questions, we utilize data about Latino participation in civic affairs derived from the Latino National Survey augmented with qualitative data obtained from focus groups conducted in a major Mid-western metropolitan area.

\section{Civic Engagement of Latino Immigrants in the United States}

A crucial feature of the civic engagement of Latino immigrants is the long history of Latino activism in the United States (Orosco, 2008). Throughout the twentieth century, Latino activists such as César Chávez have been credited for inspiring Latinos to fight for equal representation and just policy (Espinosa, 2007; National Park Service, 2009; Orosco, 2008). By uniting diverse constituencies on common interests, Chávez and other Latino activists successfully organized large and powerful protests that impacted policy on a large scale (Anonymous, 2009; Espinosa, 2007; Orosco, 2008).

In the Spring of 2006, in unified opposition to the repressive anti-immigration House Bill HR4437, 102 marches were organized across the country using Chávez's model of organizing, fasting, marching, and non-violence to exert pressure on the polity to enact immigration reform (Espinosa, 2007; Silber Mohamed, 2013). Diverse groups, ranging from first-generation immigrants from Latin America and Asia to native-born American citizens, came together to fight for a just and humane immigration policy (Espinosa, 2007; Fraga et al., 2010; Pantoja, Menjívar, \& Magaña, 2008; Silber Mohamed, 2013). The marches had the intended effect of informing the public and the legislators about the harmful consequences of HR4437 (Espinosa, 2007; Fraga et al., 2010; Silber Mohamed, 2013). All undocumented immigrants would have been prosecuted, as well as the schools, health centers, community organizations, and churches that did not turn them in to Immigration and Customs Enforcement (Espinosa, 2007; Padilla, Shapiro, FernándezCastro, \& Faulkner, 2008). Not only did the 2006 marches positively affect policy change by influencing legislators to reject the bill, they also awakened a passionate group of 
people with deep activist roots. The new slogan derived from the marches, "Today we act, tomorrow we vote," seemed to be a foreshadowing of the civic power of the Latino immigrant population. (Espinosa, 2007). Since the 2006 marches, the Latino immigrant community has experienced unprecedented increases in the number of registered voters and interest in political campaigns (DeSipio, 2011; Fraga et al., 2010). In the four years from 2004 to 2008, the immigrant vote increased by more than 1.3 million (DeSipio, 2011). Moreover, since the marches, Latinos have increasingly chosen to self-identify as American, and in so doing, have gained momentum in the fight for equal rights as Americans (Silber Mohamed, 2013).

Nonetheless, continued racial and ethnic segregation of the Latino community hampers the civic engagement of Latino immigrants (Keidan, 2008; Massey, 2007; Massey \& Denton, 1993; Moore \& Pinderhughes, 1993; Pratt \& Hanson, 1994; Putnam, Frederick, \& Snellman, 2012; Sánchez-Jankowski, 2008; Sánchez Molina, 2008; Santiago \& Galster, 1995; Wilson, 1978, 1993). There is substantial evidence that race matters, and that racial discrimination impedes integration into American society (Félix, 2008; Fraga et al., 2010; Hernández-León, 2008; Okigbo, Reierson, \& Stowman, 2009; Portés, 1997; Rivas-Drake \& Mooney, 2009; Toussaint-Comeau, 2006; Waldinger, Lim, \& Cort, 2007). Even when newcomers with visible physical differences from those of the dominant population of white Americans adopt behaviors of mainstream society, they may still experience social rejection in stores, restaurants, schools, housing, and employment, thereby increasing their chances of joining a racialized 'underclass' (e.g. Brown, 2007; Golash-Boza, 2006; Michelson, 2003; O'Brien, 2008; Parrado \& Morgan, 2008; Piedra \& Engstrom, 2009; Portés \& Rumbaut, 2001, 2006; Portés \& Zhou, 1993; Rumbaut \& Portés, 2001; Wilson, 1993). This segmented 'underclass' group consists of other racial minorities who have not fully integrated into mainstream society and often struggle with social and economic injustice (Wilson, 1993). When social interactions only transpire within these racialized minority groups, decision makers in the larger society do not hear their voices (Félix, 2008; Hernández-León, 2008; Okigbo et al., 2009; Portés, 1997; Rivas-Drake \& Mooney, 2009; Toussaint-Comeau, 2006; Waldinger et al., 2007). Therefore, their interests are not adequately reflected in the decisions made and in the public goods created.

Several recent studies have found that the newest waves of immigrants to the United States have had remarkably different experiences with acculturation than did previous waves of immigrants of European ancestry (Barvosa, 2006; Fraga et al., 2010; Monzó \& Rueda, 2006; Smith, 2008). Golash-Boza (2006) found that discrimination based on race and skin color was associated with diminished assimilation of the Latino community in the United States. More contemporary models of acculturation, such as Berry's (2002), describe a multidimensional process whereby immigrants maintain varying degrees of their original culture, adopt various aspects of the new culture, and influence the larger American society with aspects of their cultural heritage such as traditions, celebrations, foods, dress, music, and the arts (Barvosa, 2006; Ben-Shalom \& Horenczyk, 2003; Berry, 2002; Fraga et al., 2010; Monzó \& Rueda, 2006; Smith, 2008). This model offers a strengths-based approach to acculturation by emphasizing the contributions each culture makes to American society, as well as how individual adoption of certain aspects of 
American culture facilitates access to goods and services within American society. As stressed by Fraga and colleagues (2010), Latino immigrants do adapt to mainstream American culture, adopting certain behaviors and practices expected in the workplace, in school environments, and the political landscape, in order to get ahead. Implicit in this adaptation/acculturation process is the knowledge that in order to get ahead in American society, one must often interact with, work with, and be represented by the majority (Fraga et al., 2010).

A weakness of previous studies of civic engagement has been the minor role afforded ethnicity and race (Correia, 2010; Fraga et al., 2010). There have been many more civic engagement studies about the white majority than racial minorities (Fraga et al., 2010; Portney \& Berry, 1997). In part, this may be because civic engagement, as defined by Putnam (1995, 2000, 2005), is encapsulated in a language of the majority, and as such, is most easily understood and measured by the white majority citizenry. However, as Fraga and colleagues (2006) have argued, it is especially important to consider all aspects of American identity in the study of civic engagement, including the understanding of race and ethnicity. Immigrant involvement in politics and in their communities is at times hindered, and at times propelled by their experiences with racial discrimination, their immigrant status, and their international politics (Bacon, 2008; García, 2003; Fraga et al., 2006; Levin, 2013; Prigoff, 2000; Telles \& Ortiz, 2008). Therefore, future conceptualization and research on civic engagement needs to be altered in order to be applicable to a racialized and increasingly immigrant society (Fraga et al., 2010).

In sum, the civic engagement of the residents of the United States is what connects the populous to those who represent them in this representative democracy. Involvement at the local, state, and national levels brings the needs, concerns, and ideas of those represented to the decision makers. If decision makers do not hear or listen to all constituencies, they cannot appropriately represent them. Policy, at any level, that does not take into account the needs of all the stakeholders is intrinsically unjust (Diamond, 1990, 1994; Son \& Lin, 2007; Tuennerman-Kaplan, 2001; Verba et al., 1995). When those impacted by unjust policy are excluded from decisions on new policy, then a vicious cycle of unjust policy ensues (Aguirre \& Turner, 1995; Bacon, 2008; Massey et al., 2002; Telles \& Ortiz, 2008).

\section{Data and Methods}

The primary data used in this study were obtained from the Latino National Survey (LNS) 2006, which examined the political views, experiences with discrimination, and levels of civic engagement of Latinos in the United States (see Fraga et al., 2008, 2010 for a detailed discussion of the research and sampling designs utilized in the $L N S$ ). A spatially-stratified random sampling technique was used to capture a representative sample of Latinos residing in one of 15 states or the District of Columbia. The sample

was further selected based on the size of the Latino population as well as the rate of Latino population growth. According to Fraga and colleagues (2008), approximately 88\% of the U.S. Hispanic population lived within the selected areas. The LNS samples were weighted by nation, state, and metropolitan area, and thus, can be used as stand-alone representations of their respective Latino populations (Fraga et al., 2008). 
In order to identify potential themes and questions, as well as to ensure that misconceptions and stereotypes about Latinos and their experiences in American society were not perpetuated in the national study, the first 15 focus groups were conducted in diverse communities throughout the United States (Fraga et al., 2010). Following the focus groups, Fraga and colleagues (2008) surveyed 8,634 Latino residents using Computer Assisted Telephone Interviewing (CATI). Fraga and colleagues (2010) acknowledge the potential limitations of telephone interviews for hard to reach participants and migrant workers who may not have had landlines at the time of the survey. Further, Dutwin, Keeter, and Kennedy (2010) note that Latinos without landlines tended to be younger, unmarried, and had higher levels of acculturation, suggesting that results from the LNS may not fully represent these subgroups of Latino immigrants. In this study, we restrict our secondary analyses of the 2006 LNS data to include only those who had immigrated to the United States and resided in one of the sampling areas. We excluded those Latino respondents who were of second or subsequent generations. Our definition of immigrant also incorporates those who were born in Puerto Rico, but were residing in the United States. This resulted in a final analysis sample of 6,239 individuals. Latino immigrants in the LNS were primarily young, female, and married. Nearly three quarters were Catholic. Slightly over half of the respondents indicated that they were brown skinned (51\%), while the remainder identified themselves as white or light skinned. Approximately half had earned less than a high school level of education. Although 7 out of 10 were employed, annual household incomes were very low, with $40 \%$ earning less than $\$ 25,000$ and $77 \%$ earning less than $\$ 35,000$. Only $40 \%$ of the respondents owned homes in the United States. Nearly two thirds of the respondents were immigrants from Mexico; the remaining individuals were from Puerto Rico, the Dominican Republic, Cuba, and other Central and South American countries. Six out of 10 immigrants came to the United States for economic reasons. The majority of respondents (60\%) had lived in the United States for more than 10 years; that same fraction expressed plans to stay permanently in the United States. Although a third were actually U.S. citizens, more than half (53\%) considered themselves to be at least somewhat American. Although over a third of the sample felt they were good English speakers (38\%), 45\% had limited English proficiency, and 17\% spoke no English at all (see Tucker, 2010 for a detailed description of sample characteristics).

In addition, we conducted a series of four 90-minute focus group interviews in Spanish with a small purposive sample of Latino immigrants $(\mathrm{N}=42)$ residing in a major Midwestern metropolitan area. According to the 2010 U.S. Census, the majority (64\%) lived in a larger neighborhood inhabited primarily by immigrants of Mexican descent (U.S. Census Bureau, 2010b). As a result, focus group participants were only those who self-identified as immigrants of Mexican descent. Approximately 80\% were under the age of 40. The majority were women (93\%). Two thirds had less than a high school level of education. Eight out of 10 participants had children enrolled in community schools. Although only $17 \%$ of the focus group participants worked outside the home, their spouses were employed at a much higher rate. Nearly half of the participants had lived in the United States for more than 10 years. Four out of 10 (43\%) were homeowners. Over half (52\%) of the participants were active in their communities (see Tucker, 2010 for further discussion of the qualitative research design). 


\section{Findings}

Figure 1 depicts the empirical model utilized in this study, and a detailed summary of our measures is provided in Table 1. Our outcome measure, civic engagement, reflects the respondent's active engagement in community affairs, political and electoral participation, and school involvement. Three sets of contextual factors, respondent demographic characteristics, socioeconomic status, and characteristics of the immigration experience, are hypothesized to directly impact civic engagement. Moreover, we assess both the direct effects of acculturation on civic engagement, as well as a moderator of our contextual factors. We hypothesize that the level of acculturation could attenuate the negative effects that some of the contextual variables such as low levels of schooling have on civic engagement. Additionally, we hypothesize that the level of acculturation could increase the effects of independent variables that have positive associations with civic engagement, such as full-time employment.

Figure 1 Empirical Model for Immigrant Civic Engagement

Contextual Factors

Demographic

Characteristics

Age

Gender

Marital status

Skin color

Religious affiliation

Socioeconomic Factors

Employment status

Educational attainment

Household income

Homeownership

Characteristics of the

Immigrant Experience

Country of origin

Reason for immigrating

Length of US residence

Permanency plans

Civic Engagement Community involvement Electoral participation School involvement

Acculturation

English language proficiency

Integrated friends

Integrated coworkers

Consider self American

Access to services in Spanish

Unfair treatment

Citizenship 
Table 1Conceptual and Operational Definitions of Variables

\begin{tabular}{|c|c|}
\hline Variables & Conceptual and Operational Definitions \\
\hline \multicolumn{2}{|l|}{ Outcome } \\
\hline Civic engagement & $\begin{array}{l}\text { Individual and community level of involvement in social and } \\
\text { political activities that attach people to society. Measured using } \\
\text { respondent self-reports of participation or membership at time of } \\
\text { survey in community groups or organizations; extent of electoral } \\
\text { participation (registering to vote, voting in the last election, } \\
\text { interest in politics); connection to U.S. government by way of } \\
\text { military service; involvement in work communities by way of } \\
\text { union membership; and involvement in local parent networks } \\
\text { through school involvement. An index of civic engagement was } \\
\text { created based on a sum of the responses to the above questions. } \\
\text { Index scores ranged from } 0 \text {, reflecting no engagement, to 5, } \\
\text { indicating a high level of engagement. }\end{array}$ \\
\hline \multicolumn{2}{|l|}{ Moderating Factor } \\
\hline Acculturation & $\begin{array}{l}\text { Level of individual integration into the dominant American } \\
\text { society and access to its social institutions. Measured using } \\
\text { respondent self-reports of English language proficiency, integrated } \\
\text { friendship networks, integrated coworker networks, consideration } \\
\text { of oneself as American, becoming a naturalized citizen, and } \\
\text { experiences of unfair treatment in the United States. For each of } \\
\text { these dimensions the variable was coded as } 1=y e s, 0=\text { otherwise. In } \\
\text { addition, access to bilingual services was measured using an index } \\
\text { based on self-reported access to social/health care services, public } \\
\text { school services, and law enforcement/legal services in Spanish. } \\
\text { Index scores ranged from } 0 \text {, reflecting no access, to } 3 \text {, indicating } \\
\text { access to the full range of services. Unfair treatment was a } \\
\text { dichotomous variable ( } 1=y e s ; 0=\text { otherwise) indicating if the } \\
\text { respondent had ever been unfairly treated in encounters with the } \\
\text { police, in employment, in finding a place to live, in being paid or } \\
\text { not paid for a job completed, or in restaurants or stores. }\end{array}$ \\
\hline
\end{tabular}

Contextual Factors

Demographic characteristics Skin color

Identification of one of the physical differences between immigrants and the dominant members of society. Measured using respondent self-report to describe respondent's skin tone or complexion shade on a five-point scale ranging from very light to dark. Recoded as a dummy variable for brown skinned from the original values of 3,4 , and 5 , and white skinned with original values of 1 and 2 .

Socioeconomic factors Household income

Refers to total income of all employed in household at time of survey. Income was recoded into five dummy variables: very low income (below $\$ 15,000$, used as the reference category); low income (\$15,000 to $\$ 24,999)$; low-moderate income ( $\$ 25,000$ to $\$ 34,999)$; moderate income (\$35,000 to $\$ 44,999)$; and higher 
Employment status

Educational attainment

Homeownership status income (above \$45,000). Missing income data were imputed using mean substitution.

Proxy for labor market involvement that included all levels of work, from not currently employed, to working occasionally, to part-time and full-time employment. This variable was recoded into a series of dummy variables representing full time employment, including working more than one job; part time employment, including occasional labor; and not part of labor force, including all those who were not employed outside of the home.

Refers to respondent's highest level of formal education completed at the time of the LNS survey. The original response set included no formal education, eighth grade or below, some high school, GED, high school graduate, some college, 4-year college degree, and graduate or professional degree. The response set was recoded into four dummy variables: less than eighth grade (set as the reference category), some high school, high school diploma or GED, and greater than a high school diploma.

Homeownership status in the United States. Measured by asking if the respondents $1=$ owned; or $0=$ rented their place of residence at the time of the LNS survey.

\section{Characteristics of immigrant experience}

Country of origin

Used to proxy form of government in the country of origin. Because of sample size restrictions, recoded to Mexico=1; $0=$ otherwise.

Length of residence in the U.S.

Length of residence in the United States. Measured by asking respondents how long they had resided in United States at time of survey.

Reason for immigrating

Distinguishes between willing migration (e.g., immigrating for economic reasons), passive migration (e.g., being brought as a child), or trauma-induced migration (e.g., escaping political turmoil). Measured using respondent self-report of reason for immigrating to the United States recoded as a dummy variable indicating 1 =migration for better life/work/economic improvement; $0=$ otherwise.

Permanency plan

Extent to which an immigrant plans on remaining in the host country. Measured using respondent self-report of intent to remain in the United States with $1=$ planning on staying permanently; $0=$ otherwise.

Demographic control variables
Respondent self-reported gender, age, marital status (1=married/partnered; $0=$ other), and religious affiliation ( 1 =Catholic; $0=$ other) at time of survey. 


\section{Civic Engagement of Latino Immigrants}

To measure the level of civic engagement of Latino immigrants, we created an index composed of indicators for community involvement, electoral participation, and school involvement. Subsequently, these index scores were categorized into low, moderate, and high levels of engagement for ease of interpretation (see Table 2.). Data analyses revealed overall low levels of civic engagement among Latino immigrants. Approximately $43 \%$ of the sample reported no civic engagement at all, $22 \%$ reported very low engagement, $29 \%$ were moderately engaged, and only $6 \%$ were highly engaged. Nonetheless, Latino immigrants showed considerably higher levels of participation in schools and politics. Specifically, respondents were most actively involved by registering to vote (77\%), if they were eligible to vote, followed by attending PTA meetings at their children's schools (76\%), if they had school-aged children. Additionally, $61 \%$ of eligible voters voted in the 2004 presidential election, and $42 \%$ of parents with school-aged children volunteered at their children's schools. Approximately one in six respondents had an immediate family member join the U.S. military and one in eight participated in community groups. However, fewer than $10 \%$ were members of a labor union in the United States.

Table 2 Civic Engagement in a National Sample of Latino Immigrants $(N=6,239) *$

\begin{tabular}{|c|c|c|}
\hline Characteristic & $\mathbf{N}$ & $\%$ of total \\
\hline \multicolumn{3}{|l|}{ Level of Civic Engagement } \\
\hline None & 2,705 & 43.3 \\
\hline Low & 1,387 & 22.2 \\
\hline Moderate & 1,794 & 28.8 \\
\hline High & 354 & 5.7 \\
\hline \multicolumn{3}{|l|}{ Forms of Civic Engagement } \\
\hline Participate in Community Groups & 791 & 12.7 \\
\hline Union Membership & 431 & 6.9 \\
\hline Family Member in the U.S. Military & 978 & 15.7 \\
\hline Attend PTA Meetings (Full sample) & 1,362 & 21.9 \\
\hline Attend PTA meetings (Sample with Children in School) ${ }^{a}$ & 1,362 & 75.7 \\
\hline Volunteer at School (Full sample) & 764 & 12.2 \\
\hline Volunteer at School (Sample with Children in School) ${ }^{\mathrm{a}}$ & 764 & 42.5 \\
\hline \multirow{2}{*}{$\begin{array}{l}\text { Registered to Vote (Full sample) } \\
\text { Registered to Vote (Sample of Eligible Voters) }\end{array}$} & 1,541 & 24.7 \\
\hline & 1,541 & 77.3 \\
\hline Voted in 2004 Presidential Election & 1,221 & 19.6 \\
\hline Voted in 2004 (Sample of Eligible Voters) ${ }^{\mathrm{b}}$ & 1,221 & 61.2 \\
\hline \multicolumn{3}{|c|}{$\begin{array}{l}\text { Notes * Sample was weighted to derive national estimates using LNS sampling weights } \\
\text { a The denominator is the 1,799 respondents with children in school. } \\
\text { b The denominator is the 1,994 respondents who are naturalized citizens or U.S. citizens born in } \\
\text { Puerto Rico. }\end{array}$} \\
\hline
\end{tabular}




\section{Level of Acculturation}

We estimated the acculturation of Latino immigrants using indicators of English language proficiency, integrated friends, integrated coworkers, consideration of oneself as American, access to services in Spanish, experience with unfair treatment, and citizenship (see Table 3). Approximately one third of Latino immigrants identified themselves as proficient in English. Over half of the sample reported having integrated friendship and coworker networks. Although one half of the immigrants in the LNS study considered themselves to be American, only a third were actually U.S. citizens. More than three quarters reported moderate to high access to bilingual social services, legal, and school services. One in three had experienced unfair treatment while residing in the United States. Thus, this sample of Latino immigrants would be portrayed as experiencing limited acculturation as measured by English language proficiency and citizenship, but relatively high levels of acculturation in terms of social and workplace integration, access to services in Spanish, as well as relatively low levels of unfair treatment.

Table 3 Levels of Acculturation in a National Sample of Latino Immigrants*

\begin{tabular}{lrr}
\hline Acculturation Indicators & N & \% of total \\
\hline English Language Proficiency & & \\
$\quad$ Speaks No English & 1,075 & 17.2 \\
$\quad$ Speaks a Little English & 2,809 & 45.0 \\
$\quad$ Speaks English Well & 709 & 11.4 \\
$\quad$ Speaks English Very Well & 1,646 & 26.4 \\
Integrated Friends & 3,479 & 55.8 \\
Integrated Coworkers & 3,410 & 54.6 \\
Considers Self American & 3,323 & 53.3 \\
Access to Services in Spanish & & \\
$\quad$ None & 396 & 6.3 \\
$\quad$ Low & 839 & 13.4 \\
$\quad$ Moderate & 1334 & 55.9 \\
$\quad$ High & 3487 & 2.9 \\
$\quad$ Not Applicable/No Need for Spanish Services & 184 & 34.0 \\
Experienced Unfair Treatment in United States & 2,121 & 32.0 \\
Citizen (naturalized or born in Puerto Rico) & 1,994 & \\
\hline N = 6,239 & & \\
* Sample was weighted to derive national estimates using LNS sampling weights & \\
\hline
\end{tabular}

In analyses not shown here, differences in means tests (t-tests and analyses of variance) were conducted to examine variations in the level of civic engagement by levels of acculturation and these contextual factors. These tests revealed significant differences $(p=.000)$ in civic engagement for all of the variables in the empirical model. Consistent with other studies on White populations (e.g., Lewis, MacGregor, \& Putnam, 
2013), we found that Latino respondents who were female, married, older, or involved in religious groups reported higher levels of civic engagement. Likewise, civic engagement increased among Latino immigrants with increasing socioeconomic status. Further, Latino immigrants who were brought to the United States as children, those who intended to stay in the United States permanently, or those who had resided in the United States for longer periods of time had higher levels of civic engagement.

In contrast, skin color, country of origin, and reason for immigration were associated with lower levels of civic engagement of Latino immigrants. Consistent with the literature on the racialized underclass, brown-skinned immigrants reported lower civic engagement than lighter-skinned immigrants. Compared to Latinos from other countries, immigrants from Mexico had the lowest civic engagement scores, lending support to the argument that proximity to the country of origin reduces incorporation.

Finally, acculturation was positively associated with civic engagement. Higher levels of civic engagement were associated with English language proficiency, integrated friendship, coworker networks, U.S. citizenship, and self-identification as American. Moreover, greater access to health, social, educational, and legal services in Spanish increased civic engagement as well. Ironically, Latino immigrants who experienced unfair treatment in the United States were more civically engaged than those who had no such experience. We suspect that experiences of unfair treatment may spur involvement in the fight for social and economic justice.

We estimated hierarchical linear regression models in order to analyze the extent to which acculturation moderated the observed effects of immigrant demographic characteristics, socioeconomic status, and characteristics of the immigrant experience on civic engagement. Thus, we were able to compare differences in the levels of civic engagement that were explained by contextual factors alone (Model 1), as well as after controlling for level of acculturation (Model 2). Results from these analyses are summarized in Table 4.

Model 1 accounted for $42 \%$ of the variance in the civic engagement scores of Latino immigrants. With the exception of religious affiliation and employment status, all of the contextual factors were significant predictors of civic engagement. After controlling for the effects of the other contextual factors, the strongest predictors of increased civic engagement of Latino immigrants were length of residence in the United States, socioeconomic status, and plan to remain permanently in the United States. Compared to recent immigrants, those who had resided in the United States for longer periods of time were between 3.9 and 25.6 times more likely to be involved in civic affairs. Relative to Latino immigrants in the lowest income category, those with higher incomes were between 2 and 11 times more likely to be involved in civic affairs. Relative to those who believed that their immigration to the United States was temporary, the odds of being involved in civic affairs were 4.7 times higher for those who planned to remain permanently. In contrast to the bivariate results, the most significant predictors of lower levels of civic engagement were being an immigrant from a country other than Mexico (9.6 times lower odds), immigrating to the United States for non-economic reasons (5.6 times lower odds), or being brown skinned (2.7 times lower odds). 
Table 4 Predictors of Civic Engagement of Latino Immigrants

\begin{tabular}{|c|c|c|c|c|c|c|}
\hline \multirow[t]{2}{*}{ Variables } & \multicolumn{3}{|c|}{ Model 1} & \multicolumn{3}{|c|}{ Model 2} \\
\hline & $\mathbf{B}$ & SEB & $t$ & $\mathbf{B}$ & SEB & $t$ \\
\hline \multicolumn{7}{|l|}{ Demographic Characteristics } \\
\hline \multicolumn{7}{|l|}{ Age at time of survey (omitted=under 30) } \\
\hline 30-39 & .197 & .035 & $5.63 * * *$ & .315 & .030 & $10.41 * * *$ \\
\hline $40-49$ & .154 & .038 & $4.02 * * *$ & .322 & .033 & $9.68 * * *$ \\
\hline 50 and over & .172 & .045 & $3.79 * * *$ & .241 & .039 & $6.10^{* * *}$ \\
\hline Gender (omitted=male) & .154 & .026 & $5.87 * * *$ & .185 & .023 & $8.21 * * *$ \\
\hline Skin color (omitted=White) & -.066 & .025 & $-2.67 * *$ & -.050 & .021 & $-2.39 *$ \\
\hline Marital status (omitted=not married) & .111 & .027 & $4.16 * * *$ & .170 & .023 & $7.49 * * *$ \\
\hline Religious affiliation (omitted=not Catholic) & -.010 & .028 & -.37 & .015 & .024 & .63 \\
\hline \multicolumn{7}{|l|}{ Socioeconomic Factors } \\
\hline Employment status (omitted=not employed) & -.003 & .029 & -.09 & .016 & .025 & .65 \\
\hline \multicolumn{7}{|l|}{ Educational attainment (omitted $=<$ high school) } \\
\hline Some high school & .077 & .036 & $2.14 *$ & .002 & .031 & .05 \\
\hline High school diploma or GED & .274 & .034 & $8.11^{* * *}$ & .118 & .029 & $4.03 * * *$ \\
\hline Above high school & .544 & .036 & $14.97 * * *$ & .228 & .033 & $6.97 * * *$ \\
\hline \multicolumn{7}{|l|}{ Household income (omitted $=<\$ 15,000$ ) } \\
\hline$\$ 15,000-\$ 24,999$ & -.026 & .034 & $2.14 *$ & -.052 & .029 & -1.81 \\
\hline$\$ 25,000-\$ 34,999$ & .138 & .044 & $3.14 * *$ & .081 & .037 & $2.17 *$ \\
\hline$\$ 35,000-\$ 44,999$ & .229 & .052 & $4.41 * * *$ & .093 & .044 & $2.10^{*}$ \\
\hline$\$ 45,000$ or more & .510 & .048 & $10.58 * * *$ & .272 & .042 & $6.53 * * *$ \\
\hline Homeownership (omitted=renter) & .222 & .028 & $7.81^{* * *}$ & .126 & .024 & $5.17^{* * *}$ \\
\hline \multicolumn{7}{|l|}{ Characteristics of the Immigrant Experience } \\
\hline Country of origin (omitted=other than Mexico) & -.275 & .029 & $-9.60 * * *$ & -.096 & .025 & $-3.90 * * *$ \\
\hline Reason for immigrating (omitted=non-economic) & -.154 & .027 & $-5.62 * * *$ & -.036 & .024 & -1.51 \\
\hline \multicolumn{7}{|l|}{$\begin{array}{l}\text { Length of residence in the US (in years) (omitted }=5 \text { or } \\
\text { fewer) }\end{array}$} \\
\hline $6-10$ years in United States & .151 & .039 & $3.85^{* * *}$ & .039 & .034 & 1.17 \\
\hline $11-20$ years in United States & .507 & .041 & $12.49 * * *$ & .151 & .036 & $4.20 * * *$ \\
\hline More than 20 years in United States & 1.197 & .047 & $25.63 * * *$ & .442 & .043 & $10.23^{* * *}$ \\
\hline Plans to stay in United States (omitted=return home) & .124 & .027 & $4.69 * * *$ & .044 & .023 & 1.92 \\
\hline \multicolumn{7}{|l|}{ Acculturation } \\
\hline English Proficiency (omitted=not proficient) & & & & .096 & .013 & $7.19^{* * *}$ \\
\hline Integrated Friends (omitted=not integrated) & & & & .068 & .023 & $2.94 * *$ \\
\hline Integrated Coworkers (omitted=not integrated) & & & & .063 & .023 & $2.74^{* *}$ \\
\hline Consideration of Oneself as American (omitted=not & & & & .108 & .022 & $4.83^{* * *}$ \\
\hline \multicolumn{7}{|l|}{ American) } \\
\hline US Citizen (omitted=not citizen) & & & & 1.241 & .028 & $44.13^{* * *}$ \\
\hline Unfair Treatment (omitted=no unfair treatment) & & & & .118 & .022 & $5.29 * * *$ \\
\hline \multicolumn{7}{|l|}{ Access to Spanish Services (omitted=no access) } \\
\hline Low access & & & & .004 & .044 & .09 \\
\hline Moderate access & & & & .096 & .041 & $2.36^{*}$ \\
\hline High access & & & & .133 & .037 & $3.62 * * *$ \\
\hline \multicolumn{7}{|c|}{$\begin{array}{ll}\text { Notes: } \mathrm{N}=6,238 * * * \mathrm{p}<.001, * * \underline{\mathrm{p}}<.01, * \mathrm{p}<.05 \\
\text { Model 1: Adjusted } \underline{\mathrm{R}^{2}}=.420, \mathrm{~F}=206.35^{* * *} . \text { Model } 1 \text { constant: } \mathrm{B}=.163, \mathrm{SEB}=.063, t=2.59 * \\
\text { Model 2: Adjusted } \underline{\mathrm{R}^{2}}=.583, \mathrm{~F}=257.53^{* * *} . \text { Model } 3 \text { constant: } \mathrm{B}=-.399, \mathrm{SEB}=.067, t=-5.99 * * *\end{array}$} \\
\hline
\end{tabular}


In Model 2, we introduced our acculturation measures as moderators for the aforementioned contextual factors. As shown in Table 4, the inclusion of acculturation in the empirical model increased the amount of explained variance in the civic engagement scores of Latino immigrants to 58\%. All of the acculturation indicators were statistically significant predictors of increased civic engagement. Holding U.S. citizenship increased the odds of participating in civic affairs by 44\%. Being English proficient, selfidentification as American, and having integrated friendship and work networks increased the odds of participating in civic affairs by factors of 7.2, 4.8, and 2.9, respectively.

Further, acculturation was found to moderate the effects of immigrant demographic characteristics, socioeconomic status, and characteristics of the immigrant experience on the levels of civic engagement of Latino immigrants. We found that the positive effects associated with respondent age, gender, and marital status were further accentuated after controlling for level of acculturation. Conversely, we found that although skin color and socioeconomic status variables remained statistically significant predictors of civic engagement, the effect of these variables was attenuated once we controlled for differences in levels of acculturation. Finally, the significant effects on civic engagement of planning to remain permanently in the United States and reasons for immigrating disappeared once we accounted for variations in levels of Latino immigrant acculturation.

\section{The Contexts Associated with the Civic Engagement of Latino Immigrants}

Qualitative data were collected to provide a deeper understanding of the contexts in which Latino immigrants are engaged in American society and the processes underlying said engagement. Our focus group discussion guide was developed based on four themes that emerged directly from our analyses of the LNS data: (1) the contexts within which the participants originally immigrated and in which they resided at the time of the study; (2) their patterns and level of civic engagement; (3) their experiences with local, state, and federal governments in the United States; and (4) their acculturation into American society. Qualitative thematic analyses were completed to better understand the factors that the focus group participants reported as influencing their levels of acculturation and civic engagement (Bazeley, 2007; Braun \& Clark, 2006; Fereday \& Muir-Cochrane, 2006; Gibbs, 2002; Klassen et al., 2012). Within each topical area, several subthemes emerged, thereby providing greater focus to the thematic coding and greater understanding of the particular situations in which the individual participants found themselves. Through the key subthemes, the focus group participants were able to illuminate the local context of anti-immigrant sentiment in which they operated daily.

Situational contexts shaping patterns of civic engagement. Data derived from our focus groups with Latino immigrants were able to provide critical information about the situational contexts shaping patterns of engagement in the metropolitan area. Further, they illuminated the role of acculturation on shaping these patterns. Table 5 provides a summary of the major themes and subthemes discussed in these focus groups. 
Table 5 Key Themes and Subthemes Discussed in Focus Groups*

\begin{tabular}{lr}
\hline Key Themes and Subthemes & Frequencies \\
\hline Barriers to Engagement & 24 \\
Lack of Citizenship - Need for Immigration Reform & 17 \\
Lack of Driver's Licenses - Need for Legislative Reform & 11 \\
Experienced Harassment by Immigration and/or Police & 16 \\
Fear of Officials/Deportation Worries & 18 \\
Importance of Civic Engagement & 12 \\
Civic Engagement through Neighborhood Pride & 14 \\
School Involvement & 25 \\
Acculturation & 10 \\
Not North American/Not Part of American Society & 4 \\
Concerns about English Language Skills & \\
Importance of Level of Education & \\
\hline * A total of 42 immigrants participated in the four focus groups & \\
\hline
\end{tabular}

The metropolitan area where the focus groups were conducted has a history of Latino immigration dating back to the early 1900s. Nonetheless, Latinos represented less than $5 \%$ of the area's population throughout most of the twentieth century (US Census, 2000). In the past decade, the area has witnessed considerable growth in the number and diversification of the Latino immigrant population (Durand, Telles, \& Flashman, 2006). Between 2000 and 2006, the Latino population increased by 20\%.

Most Latino immigrants have settled in a working class neighborhood located on the southwest side of town. By 2010, the Latino population had grown to $69.6 \%$, while the percentage of Mexican descendants increased even more so to $82.9 \%$ of all Latino residents (American Fact Finder, 2010). These population changes increased the potential for interethnic conflict.

Economic growth within this Latino community has not been well documented. Notwithstanding, our field observations, as well as those made by our focus group participants, suggest significant growth in the number of Latino-owned small businesses during the past decade. These include numerous retail establishments, restaurants, and grocery stores.

However, as public sentiments toward undocumented immigrants have become increasingly harsh across the nation, the metropolitan area has witnessed a similar rise in anti-immigrant attitudes and behaviors. Since 2010, the local Spanish language newspaper has reported increased raids by immigration authorities within the Latino community. Furthermore, conversations with our focus group participants touched on these experiences as well. It is within this context of economic and population growth in the midst of growing anti-immigrant rhetoric and atmosphere that our focus groups were held. The findings from these groups suggest the need for further research on the manner 
in which Latino immigrants become engaged within the community, regardless of their legal status.

Slightly more than half of the focus group participants (52\%) reported being involved in community affairs. One tangible way in which participants became engaged in their communities has been through community building efforts in their neighborhoods. Nearly one half of our focus group participants owned their homes and reported making major improvements both to their homes and the surrounding neighborhoods by cleaning up areas previously abandoned or riddled with graffiti. Further, they helped develop commercial activities in an area that once was desolate and offered few retail options. Now there are many restaurants, stores, gardens, and well-maintained houses.

Nearly one third of the participants were engaged in their community through involvement in local schools. One woman ran for office at her children's school and became the PTA president. This level of civic engagement connected her to local issues and gave the Latino community a voice in district policy.

The focus group interviews shed light on the barriers to civic engagement faced by immigrants residing in the United States. Focus group participants identified the lack of U.S. citizenship as the largest barrier to civic engagement within the Latino community. As one participant who had been in the United States for 10 years eloquently stated, "Without papers, [we have] neither voice nor vote." Further, the desire for immigration reform and equalization of status in the United States was raised 24 times by group participants. One woman who attained her GED has become outspoken about the need to participate in politics to give the Latino community a voice. She observed, "Right now we don't have a voice because we don't have a vote. Right now we are nobody. We need to change that, we don't have an identity in this country."

In addition to voting rights, study participants underscored the deleterious effect of a current immigration policy that fosters an environment of harassment, fear of deportation, a mistrust of government officials, and their subsequent avoidance of public forums, government offices, representatives, and in many cases any activities outside of work and school. As one participant described, "I don't go out. I would love to participate, but I am afraid of the police and of immigration [ICE] because of the license. Now, I don't go out.” This issue of obtaining a valid driver's license, one of the key legal documents that conveys identity as well as enables mobility in the United States, came up 17 times in the four groups.

Three of the four groups noted the increased presence of immigration officers in their neighborhoods and at their workplaces. Eleven participants spoke of harassment by the police and immigration officers. A woman who came from a small town in southern Mexico, and who has been here for 16 years, recounted a story of a police officer pulling her over just to have the immigration officer quickly drive in and demand her papers. Participants expressed fear of immigration officials and of being deported 16 times. Similarly, a young woman who has been here for 6 years revealed that her husband had been deported and she was left behind with her children trying to figure out what to do. In addition, focus group participants identified an array of indirect barriers to civic engagement associated with the lack of legal resident status or citizenship in the United 
States. Although these two issues are not mutually exclusive, they seem to be discussed as if they represented the same phenomenon. A 27-year-old woman who has lived in the area for 5 years and who owns her own home told the group that she had not been involved in community issues because of fear. However, she noted, "We must all participate in the community and in the marches [for immigration reform] with or without papers [legal immigration papers] to make change.”

Eight participants associated their limited involvement in community issues with a lack of confidence in their English language skills. These participants reported often remaining silent, even when they were being mistreated. One woman with less than a high school level of education and limited English language proficiency said, "they treat us like less [of a person] in the stores because of our accent and because we don't speak English.” Several group members described being yelled at, humiliated, scorned, or simply ignored due to their poor English language skills. A 37-year-old woman, who owned her own home and had become involved in several community groups, said that she decided on her own that she would overcome this obstacle and began to take English language classes.

While not conscious of its influence, and minimally addressed directly in the groups, level of education appeared to be a facilitator of civic engagement. Participants with higher levels of schooling (high school and beyond) tried to teach other participants how to get involved. As one woman with a high school diploma asserted, "We do have a voice. We can move many. We just have to participate." Additionally, four other participants encouraged their fellow group members to get to know their rights as immigrants and told them not to be afraid to get involved.

In sum, many of the Latino immigrants who participated in the focus group discussions had engaged in the local community. They took classes to learn English. They also purchased homes and improved their neighborhoods. Their children were enrolled in local schools. These participants held jobs and paid taxes. However, they expressed difficulty engaging in American society because of the discrimination they encountered across many contexts. They expressed heightened concern about what they consider to be failed immigration policy, increased police harassment, local immigration raids, and the deportation of family members. They expressed interest in participating more in civic affairs, but found it very difficult to become involved within a society in which they feared officials and often lived without proper identification.

\section{Discussion}

Findings based on the LNS data indicate that acculturation exerts both a direct effect, as well as a moderating effect on civic engagement. Data from both the national sample and the smaller purposive sample of immigrants suggest areas for improvement to enhance Latino immigrant involvement in local, state, and national civic and societal affairs. Given the strong positive effect of acculturation on civic engagement, some of this improvement could be made in the area of incorporating newcomers into American society in a culturally sensitive manner. Using Berry's (2002) multidimensional acculturation model, Latino immigrants could be encouraged to celebrate their cultural 
heritage, to strengthen their cultural identity, share their culture with American society, as well as adopt positive characteristics and practices of the American culture. This incorporation has the potential to not only increase current levels of engagement, but also to ameliorate some of the barriers to engagement that cannot be changed intrinsically (e.g., country of origin, skin color) (Fraga et al., 2010). Although focus group participants did not identify these factors as implicitly keeping them from becoming engaged in civic life, they did relate how feeling unwelcome led them to avoid involvement in a society that did not elicit their participation, and in some cases shunned them. The study identified barriers to engagement that could be tackled directly with proactive social policy. These include programs to improve English language skills, education levels, income levels, employment levels, and citizenship. These socioeconomic factors proved to be very important in whether Latino immigrants engaged civically. Such diversityoriented social policy has the added potential of influencing the broader American antiimmigrant sentiment as well. As individuals and groups with the propensity to blame immigrants and attempt exclusionary practice see immigrant-inclusive policy at all levels, they will have less powerful fuel for their fire.

In order to facilitate the maximum participation of Latino immigrants in American society, the right to vote and the right to legislative representation must be expanded. Without these rights, immigrants face undeniable barriers to their engagement, while still being affected by policy decisions made at all levels of society. Citizenship was found to be the strongest predictor of engagement; therefore, future efforts to increase access to naturalization and broaden eligibility requirements would influence all levels of civic engagement.

While naturalization is part of the ongoing debate over immigration reform, an avenue towards legal residency for the estimated 11 million undocumented immigrants in the United States at this time has been fiercely contested (Johnson, 2013). However, the contention arises most fervently when discussing citizenship/naturalization, and thus the right to vote for these millions. President Obama, in a speech on January 29, 2013, said, "We need Congress to act on a comprehensive approach that finally deals with the 11 million undocumented immigrants who are in the country right now. That's what we need" (Johnson, 2013). President Obama, in the same speech, alluded to proposals for updating the guest worker programs, legal residence, and expanded educational opportunities for these 11 million immigrants (Johnson, 2013).

The National Immigrant Law Center, and Services Immigrant Rights and Education Network support such naturalization efforts. Specifically, they argue that Latino immigrants would benefit from state and federal prioritization of naturalization services (CIPC, 2007). This is a policy consideration that could be coordinated with broader immigration reform or addressed separately. This prioritization could take the shape of creating programs to disseminate information regarding naturalization eligibility and application processes throughout immigrant communities. Additionally, efforts should target decreasing the cost of applying, reducing the obstacles in seeking naturalization, and increasing the opportunities for English language learning and American civics lessons (CIPC, 2007). 
Naturalization services could also take the form of multidimensional acculturation programming in immigrant communities. This study suggests that policies aimed at acculturating Latino immigrants, by not only strengthening their own cultural identity, but also by integrating their neighborhoods, schools, community groups and work places, has the potential to increase their civic engagement. There is a precedent in the profession of social work for naturalization services and immigration programming with the twentieth century settlement houses that held many community groups and forums for immigrants (Chung Yan \& Lauer, 2008; Karger \& Stoesz, 2005). These efforts also provided English language classes and venues for ethnic celebrations. Such programs could provide the link between the need to acculturate and the desire to become civically engaged, as expressed by the Latino immigrants we interviewed (Chung Yan \& Lauer, 2008).

In keeping with the model presented by César Chávez, community marches could be the most powerful venue for community activists to elicit participation within the Latino immigrant community (Espinosa, 2007; Orosco, 2008). Civil demonstration is a forum understood and accepted in the Latino immigrant community. The movement has grown since the resurgence of the marches in May 2006, following the passage of California's Proposition 187, which denied access to social, health, and educational services for undocumented immigrants (Espinosa, 2007). The focus group participants who were afraid to interact with the government had negative experiences that they associated with discrimination based on their physical appearance and their Spanish accent. However, some of the most vocal individuals in the groups had experienced discrimination and racial profiling, but had been educated about their rights in the United States. They began to teach the others to stand up for their rights and seek appropriate representation through their state representative and the local office in their neighborhood. These few individuals with the power to inspire the group towards activism corroborated the statistical findings that showed some increased engagement of those who had experienced racial discrimination. Community leaders could use similar marches and rallies to organize Latino immigrants to participate in local, state, and national issues. They could use the energy and eager participation that emerge from such marches to organize the community to identify, understand, and advocate for new legislation to address their needs, inclusive of, but not limited to immigration reform.

Consistent with the literature, English language proficiency was associated with higher levels of civic engagement in this study. Moreover, because the study showed English speakers to be more civically engaged than non-English speakers, teaching English language skills to immigrants could facilitate their involvement within their communities. English language ability, or lack thereof, has dominated the rhetoric surrounding immigration, citizenship, and assimilation for decades (Abraído-Lanza, Armbrister, Flórez, \& Aguirre, 2006; Ben-Shalom \& Horenczyk, 2003; Lieberson, 1980; Massey et al., 2002; Michelson, 2003). However, the learning of English has been used as a divisive tool and suggested as a mandate in order to attain certain rights and benefits in American society, such as citizenship (Golash-Boza, 2006; Massey et al., 2002; Rumbaut \& Portes, 2001). In several cases, focus group participants who knew their state representative had greater English language skills and higher levels of education attained 
in the United States. This study suggests that if English language proficiency was facilitated and encouraged, it could facilitate civic engagement as well.

\section{Conclusion}

The results of this study contribute to our knowledge of civic engagement by examining a minority group seldom studied - Latino immigrants -- as well as by investigating how their acculturation into mainstream American society influences their engagement. When considering the many barriers to engagement facing the Latino immigrant population in the United States, it is easy to understand the low levels of civic engagement present in the study findings. Latino immigrants who are the most civically engaged share the following characteristics: U.S. citizenship, female gender, married or cohabitating, older than 30, at least a high school level of education, income over $\$ 35,000$ per year, homeownership, white skin color, proficiency in the English language, selfidentified as American, came to the United States for noneconomic reasons, not from Mexico, and integrated friendships and coworkers. However, these characteristics are less important for engagement when the participants are integrated into American society. Furthermore, this study uncovered a complex relationship between Latino immigrants' demographic characteristics, their experiences with discriminatory practices and policies, and civic engagement. According to the focus group participants, this complex relationship takes roots in the anti-immigrant sentiment in which they reside and work, as well as in discriminatory policies that make them fearful of participation in their community. Finally, local, state, and federal policies have the potential to incorporate Latino immigrants more successfully into American society and thus increase their civic engagement by facilitating their naturalization, English language acquisition, higher education, higher wages, and integrated neighborhoods and work places.

\section{References}

Abraído-Lanza, A., Armbrister, A., Flórez, K., \& Aguirre, A. (2006). Toward a theorydriven model of acculturation in public health research. American Journal of Public Health, 96(8), 1342-1346.

Aguirre, A., \& Turner, J. (1995). American ethnicity: The dynamics and consequences of discrimination. New York: McGraw-Hill.

American Fact Finder. (2010). Fact sheet 48209. Retrieved from http://factfinder2.census.gov/faces/tableservices/jsf/pages/productview.xhtml?pid=D EC 10 DP DPDP1

Anonymous. (2009). César Chávez and the United Farm Workers. El Chicano Weekly, 46(14), 16-17.

Bacon, D. (2008). Illegal people. Boston, MA: Beacon Press.

Barvosa, E. (2006). American immigrants in American conflict. Georgetown Journal of International Affairs, 7(1), 7-14.

Bazeley, P. (2007). Qualitative data analysis with NVivo. London, England: Sage. 
Ben-Shalom, U., \& Horenczyk, G. (2003). Acculturation orientations: A facet theory perspective on the bidimensional model. Journal of Cross Cultural Psychology, 34(2), 176-188.

Berry, J. (2002). Conceptual approaches to acculturation. In K. Chun, P. Balls-Organista, \& G. Marin (Eds.), Acculturation (pp.17-37). Washington, DC: American Psychological Association.

Borden, L., \& Serido, J. (2009). From participant to engaged citizen: A developmental journey. Journal of Community Psychology, 37(4), 423-438.

Braun, V., \& Clarke, V. (2006). Using thematic analysis in psychology. Qualitative Research in Psychology, 3(2), 77-101.

Brown, S. (2007). Delayed spatial assimilation: Multigenerational incorporation of the Mexican-origin population in Los Angeles. City \& Community, 6(3), 193-209.

California Immigrant Policy Center (CIPC). (2007). California must prioritize citizenship. Retrieved from http://www.caimmigrant.org/policy_center.html

Carlsen, L. (2009). The new bilateral relationship and immigration reform. Americas Program Commentary. Washington, DC: Center for International Policy.

Chung Yan, M., \& Lauer, S. (2008). Social capital and ethno-cultural diverse immigrants: A Canadian study on settlement house and social integration. Journal of Ethnic and Cultural Diversity in Social Work, 17(3), 229-250.

Correia, M. E. (2010). Determinants of attitudes toward police of Latino immigrants and non-immigrants. Journal of Criminal Justice, 38, 99-107.

Creswell, J. W. (2012). Data analysis and representation. In J.W. Creswell, Qualitative inquiry and research design: Choosing among five approaches (3rd ed.) (pp. 178211). Thousand Oaks, CA: Sage Publications.

Deaux, K. (2011). An immigrant frame for American identity. Applied Developmental Science, 15(2), 70-72.

Délano, A. (2011). México and its diaspora in the United States: Policies of emigration since 1848. Cambridge: Cambridge University Press.

DeSipio, L. (2006). Latino civic and political participation. In M. Tienda \& F. Mitchell (Eds.) Hispanics and the future of America (pp. 447-479). Washington, DC: The National Academies Press.

DeSipio, L. (2011). Immigrant incorporation in an era of weak civic institutions: Immigrant civic and political participation in the United States. American Behavioral Scientist, 55(9), 1189-1213.

de Souza Briggs, X. (2008). Democracy as problem solving: Civic capacity in communities across the globe. Cambridge, MA: The MIT Press.

Diamond, L. J. (1990). Three paradoxes of democracy. Journal of Democracy, 1(3), 4860. 
Diamond, L. J. (1994). Toward democratic consolidation. Journal of Democracy, 5(3), 417.

Durand, J., Telles, E., \& Flashman, J. (2006) The demographic foundations of the Latino population. In M. Tienda \& F. Mitchell (Eds.), Hispanics and the future of America (pp. 66-99). Washington, DC: The National Academies Press.

Dutwin, D., Keeter, S., \& Kennedy, C. (2010). Bias from wireless substitution in surveys of Hispanics. Hispanic Journal of Behavioral Sciences, 32(2), 309-328.

Espenshade, T. J., \& Hempstead, K. (1996). Contemporary American attitudes toward U.S. immigration. International Migration Review, 30(2): 535-570.

Espinosa, G. (2007). Today we act tomorrow we vote: Latino religions, politics, and activism in contemporary U.S. civic society. Annals of the American Academy of Political and Social Science, 612(1), 152-171. doi: 10.1177/0002716207301099

Félix, A. (2008). New Americans of diasporic nationalists? Mexican migrant responses to naturalization and implication for political participation. American Quarterly, 60(3), 601-624.

Fereday, J., \& Muir-Cochrane, E. (2006). Demonstrating rigor using thematic analysis: A hybrid approach of inductive and deductive coding and theme development. International Journal of Qualitative Methods, 5(1), 1-11.

Fischer, C., \& Mattson, G. (2009). Is America fragmenting? Annual Review of Sociology, 35(1), 435-455.

Fischer, M. J., \& Tienda, M. (2006). Redrawing spatial color lines: Hispanic metropolitan dispersal, segregation, and economic opportunity. In M. Tienda \& F. Mitchell (Eds.), Hispanics and the future of America (pp. 100-137). Washington, DC: The National Academies Press.

Fraga, L., García, J., Hero, R., Jones-Correa, M., Martinez-Ebers, V., \& Segura, G. (2006). Su casa es nuestra casa: Latino politics research and the development of American political science. The American Political Science Review, 100(4), 515-521.

Fraga, L., García, J., Hero, R., Jones-Correa, M., Martinez-Ebers, V., \& Segura, G. (2010). Latino lives in America: Making it home. Philadelphia, PA: Temple University Press.

Fraga, L., García, J., Hero, R., Jones-Correa, M., \& Segura, G. (2008). Latino national survey. Retrieved from the University of Michigan, Resource Center for Minority Data Web site: doi: 10.3886/ICPSR20862

García, J. (2003). Latino politics in America. New York, NY: Rowman \& Littlefield.

Gibbs, G. R. (2002). Qualitative data analysis: Explorations with NVivo. Buckingham, England: Open University Press.

Golash-Boza, T. (2006). Dropping the hyphen? Becoming Latino(a)-American through racialized assimilation. Social Forces, 85(1), 27-55. 
Hernández-León, R. (2008). Metropolitan migrants. Berkeley, CA: University of California Press.

Hero, R., García, F. C., García, J., \& Pachon, H. (2000). Latino participation, partisanship, and office holding. Political Science and Politics, 33(3), 529-534.

Hondagneu-Sotelo, P. (1999). Women and children first: New directions in antiimmigrant politics. In S. Coontz, M. Parson, \& G. Raley (Eds), American families: A multicultural reader (pp. 288-304). New York, NY: Routledge.

Johnson, B. (2013). President Obama and Immigration Reform. World News. Retrieved from http://worldnews.about.com/od/unitedstates/a/President-Obama-AndImmigration-Reform.htm

Karger, H. J., \& Stoesz, D. (Eds.). (2005). American social welfare policy: A pluralist approach ( $4^{\text {th }}$ ed.). Boston, MA: Pearson Education, Inc.

Keidan, G. (2008). Latino outreach strategies for civic engagement. National Civic Review, 97(4), 31-38.

Klassen, A. C., Creswell, J., Plano Clark, V. L., Smith, K. C., \& Meissner, H. I. (2012). Best practices in mixed methods for quality of life research. Quality of Life Research, 21(3), 377-380.

Levin, I. (2013). Political inclusion of Latino immigrants: Becoming a citizen and political participation. American Politics Research. Advance online publication. Retrieved from http://apr.sagepub.com/content/early/2013/01/07/1532673X12461438.full.pdf+html

Lewis, V. A., MacGregor, C. A., \& Putnam, R. D. (2013). Religion, networks, and neighborliness: The impact of religious social networks on civic engagement. Social Science Research, 42(2), 331-346.

Lieberson, S. (1980). A piece of the pie. Berkeley, CA: University of California Press.

Massey, D. S. (2007). Categorically unequal: The American stratification system. New York, NY: Russell Sage Foundation.

Massey, D. S., \& Denton, N. A. (1993). American apartheid: Segregation and the making of the underclass. Cambridge, MA: Harvard University Press.

Massey, D. S., Durand, J., \& Malone, N. (2002). Beyond smoke and mirrors: Mexican immigration in an era of economic integration. New York, NY: Russell Sage Foundation.

McBride, A., Sherraden, M., \& Pritzker, S. (2006). Civic engagement among low-income and low-wealth families: In their words. Family Relations, 55(2), 152-162.

Michelson, M. (2003). The corrosive effect of acculturation: How Mexican Americans lose political trust. Social Science Quarterly, 84(4), 918-933. 
Monzó, L. D., \& Rueda, R. (2006). A sociocultural perspective on acculturation: Latino immigrant families negotiating diverse discipline practices. Education and Urban Society, 38(2), 188-203.

Moore, J., \& Pinderhughes, R. (Eds.). (1993). In the barrios: Latinos and the underclass debate. New York, NY: Russell Sage Foundation.

Muñoz, C. B. (2008). Transnational tortillas: Race, gender, and shop-floor politics in Mexico and the United States. Ithaca, NY: ILR Press.

National Park Service (NPS), U.S. Department of the Interior. (2009, Spring). Agent of change: Honoring the center of the American farm worker movement. Common Ground. Retrieved from http://commonground.cr.nps.gov/02_newsCloseup.cfm?past_issue=Spring_2009\&pa ge $=1$

O'Brien, E. (2008). The racial middle: Latinos and Asian Americans living beyond the racial divide. New York, NY: New York University Press.

Okigbo, C., Reierson, J., \& Stowman, S. (2009). Leveraging acculturation through action research. Action Research, 7(2), 127-142.

Orosco, J-A. (2008). César Chávez and the common sense of nonviolence. Albuquerque, NM: University of New Mexico Press.

Padilla, Y, Shapiro, E., Fernández-Castro, M., \& Faulkner, M. (2008). Our nation's immigrants in peril: An urgent call to social workers. Social Work, 53(1), 5-8.

Pantoja, A., Menjívar, C., \& Magaña, L. (2008). The Spring marches of 2006: Latinos, immigration, and political mobilization in the 21st century. American Behavioral Scientist, 52(4), 499-506.

Papademetriou, D., \& Terrazas, A. (2009). Immigrants and the current economic crisis: Research evidence, policy challenges, and implications. Washington, DC: Migration Policy Institute. Retrieved from http://www.migrationpolicy.org/pubs/lmi_recessionjan09.pdf

Parrado, E., \& Morgan, P. (2008). Intergenerational fertility among Hispanic women: New evidence of immigrant assimilation. Demography, 45(3), 651-671.

Passel, J. (2005). Estimates of the size and characteristics of the undocumented. Retrieved from http://pewhispanic.org/reports/report.php?ReportID=107

Passel, J. (2009). A portrait of unauthorized immigrants in the United States. Retrieved from http://pewhispanic.org/reports/report.php?ReportID=107

Perea, J. F. (Ed). (1997). Immigrants out! The new nativism and the anti-immigrant impulse in the United States. New York: New York University Press.

Pew Hispanic Center. (2007). Statistical portrait of Hispanics in the United States, 2007. Retrieved from http://pewhispanic.org/files/factsheets/hispanics2007/Table-1.pdf 
Piedra, L., \& Engstrom, D. (2009). Segmented assimilation theory and the life model: An integrated approach to understanding immigrants and their children. Social Work, 54(3), 270-277.

Piore, M. J. (1979). Birds of passage: Migrant labor and industrial societies. Cambridge, MA: Cambridge University Press.

Portés, A. (1997). Immigration theory for a new century: Some problems and opportunities. The International Migration Review, 31(4), 799-825.

Portés, A., \& Rumbaut, R. (2001). Legacies: The story of the immigrant second generation. Berkeley, CA: University of California Press.

Portés, A., \& Rumbaut, R. (2006). (3rd ed.) Immigrant America: A portrait. Berkeley, CA: University of California Press.

Portés, A., \& Zhou, M. (1993). The new second generation: Segmented assimilation and its variants among post-1965 immigrant youth. Annals of the American Academy of Political and Social Science, 530, 74-96.

Portney, K., \& Berry, J. (1997). Mobilizing minority communities. American Behavioral Scientist, 40(5), 632-644.

Pratt, G., \& Hanson, S. (1994). Geography and the construction of difference. Gender, Place \& Culture: A Journal of Feminist Geography, 1(1), 5-30.

Prigoff, A. (2000). Economies for social workers: Social outcomes of economic globalization with strategies for community action. Belmont, CA: Wadsworth Press.

Putnam, R. (1995). Tuning in, tuning out: The strange disappearance of social capital in America. Political Science \& Politics, 28(4), 664-684.

Putnam, R. (2000). Bowling alone. New York, NY: Simon \& Schuster.

Putnam, R. (2005). A new movement for civic renewal. Public Management, 87(6), 7-10.

Putnam, R. D., Frederick, C. B., \& Snellman, K. (2012). Growing class gaps in social connectedness among American youth, 1975-2009. Paper session presented at the Harvard Kennedy School of Government, The Saguaro Seminar: Civic Engagement in America. Retrieved from http://www.hks.harvard.edu/var/ezp site/storage/fckeditor/file/SaguaroReport Diver gingSocialConnectedness_20120808.pdf

Rivas-Drake, D., \& Mooney, M. (2009). Neither colorblind nor oppositional: Perceived minority status and trajectories of academic adjustment among Latinos in elite higher education. Developmental Psychology, 45(3), 642-651.

Rumbaut, R., \& Portés, A. (Eds). (2001). Ethnicities: Children of immigrants in America. Berkeley, CA: University of California Press.

Saito, L. (2009). The politics of exclusion: The failure of race-neutral policies in urban America. Stanford, CA: Stanford University Press. 
Sánchez-Jankowski, M. (2008). Cracks in the pavement: Social change and resilience in poor neighborhoods. Berkeley, CA: University of California Press.

Sánchez Molina, R. (2008). Modes of incorporation, social exclusion, and transnationalism: Salvadoran's adaptation to the Washington, DC Metropolitan Area. Human Organizing, 67(3), 269-280.

Sander, H., \& Putnam, R. (2010). Still bowling alone?: The post-9/11 split. Journal of Democracy, 21(1), 9-16.

Santa Ana, O. (1999). 'Like an animal I was treated': Anti-immigrant metaphor in US public discourse. Discourse Society 10(2), 191-224.

Santiago, A. M., \& Galster, G. C. (1995). Puerto Rican segregation in the United States: Cause or consequence of economic status? Social Problems, 42(3), 361-389.

Silber Mohamed, H. (2013). Can protests make Latinos “American”? Identity, immigration politics, and the 2006 marches. American Politics Research, 41(2), 298327.

Smith, R. (2008). The case of a city where 1 in 6 residents is a refugee: Ecological factors and host community adaptation in successful resettlement. American Journal of Community Psychology, 42(3-4), 328-342.

Son, J., \& Lin, N. (2007). Social capital and civic action: A network-based approach. Social Science Research, 37, 330-349.

Stoll, M., \& Wong, J. (2007). Immigration and civic participation in a multiracial and multiethnic context. The International Migration Review, 41(4), 880-908.

Telles, E., \& Ortiz, V. (2008). Generations of exclusion: Mexican Americans, assimilation, and race. New York, NY: Russell Sage Foundation.

Toussaint-Comeau, M. (2006). The occupational assimilation of Hispanic immigrants in the U.S.: Evidence from panel data. The International Migration Review, 40(3), 508536.

Tucker, C. M. (2010). The civic engagement of Latino immigrants in the United States. (Doctoral dissertation). Retrieved from Wayne State University Dissertations. (http://digitalcommons.wayne.edu/oa dissertations/33)

Tuennerman-Kaplan, L. (2001). Helping others, helping ourselves: Power, giving, and community identity in Cleveland, Ohio, 1880-1930. Kent, OH: Kent State University Press.

U.S. Census Bureau. (2009a). 2005-2007 American Community Survey 3-Year Estimates. Retrieved from http://factfinder.census.gov/servlet/ACSSAFFFacts?_submenuId=factsheet_0\&_sse= on 
U.S. Census Bureau. (2009b). Table 23. Michigan - Race and Hispanic Origin for Selected Large Cities and Other Places: Earliest Census to 1990. Retrieved from http://www.census.gov/population/www/documentation/twps0076/MItab.pdf

U.S. Census Bureau. (2010a). Hispanic population of the United States. Retrieved from http://www.census.gov/population/www/socdemo/hispanic/hispanic_pop_presentatio $\underline{\text { n.html }}$

U.S. Census Bureau. (2010b). United States Census 2010. Retrieved from http://www.census.gov/main/www/cen2010.html

Uslaner, E. (2008). Where you stand depends upon where your grandparents sat. Public Opinion Quarterly, 72(4), 725-740.

Uslaner, E., \& Conley, R. (2003). Civic engagement and particularized trust: The tie that binds people to their ethnic communities. American Political Research, 31(4), 331360.

Van Horn, C., Baumer, D., \& Gormley, W. Jr. (2001). Politics and public policy. Washington, DC: CQ Press.

Vedder, P., Berry, J., Sabatier, C., \& Sam, D. (2009). The intergenerational transmission of values in national and immigrant families: The role of the zeitgeist. Journal of Youth and Adolescence, 38(5), 642-653.

Verba, S., Schlozman, K. L., \& Brady, H. (1995). Voice and equality. Cambridge, MA: Harvard University Press.

Waldinger, R., Lim, N., \& Cort, D. (2007). Bad jobs, good jobs, no jobs? The employment experience of the Mexican American second generation. Journal of Ethnic and Migration Studies, 33(1), 1-35.

Wampler, B., Chávez, M., \& Pedraza, F. (2009). Should I stay or should I go? Explaining why most Mexican immigrants are choosing to remain permanently in the United States. Latino Studies, 7(1), 83-104.

Wilson, T. D. (1999). Anti-immigrant sentiment and the process of settlement among Mexican immigrants to the United States: Reflections on the current wave of Mexican immigrant bashing. Review of Radical Political Economics, 31(2), 1-26.

Wilson, W. J. (1978). The declining significance of race. Chicago, IL: The University of Chicago Press.

Wilson, W. J. (Ed.). (1993). The ghetto underclass. Newbury Park, CA: Sage.

\section{Author note:}

Address correspondence to: Cristina M. Tucker, Ph.D., email address:

cristina_tucker@yahoo.com 